\title{
PERSEPSI KONSUMEN ATAS MEREK LOKAL DAN ASING PADA KATEGORI PRODUK HEDONIK DAN UTILITARIAN
}

\author{
Kussudyarsana \\ Fakultas Ekonomi dan Bisnis, Universitas Muhammadiyah Surakarta, \\ Jl. A. Yani Pabelan Kartasura Surakarta, Telp. (0271) 717417 ext 211 \\ Kus165@ums.ac.id
}

\begin{abstract}
The objective of the research is to examine the relationship between perception of local and foreign brand toward quality product and price dimension. In order to investigate the perception toward local and foreign branding, this study used hedonic and utilitarian product. This research used questionnaire to obtain the data. One hundred samples through convinience sampling were used in this research. The result indicate that foreign brand was high score in the perception of quality and price. The study also found that there was significance differences of perception of price among local and foreign brand.
\end{abstract}

Keywords: Price, Quality, Utilitarian, Hedonic, Local Brand, Foreign Brand

\section{PENDAHULUAN}

Pasar domestik Indonesia, merupakan pasar yang sangat besar dengan jumlah penduduk diperkirakan di atas 250 juta orang (BPS 2016). Pasar domestik yang demikian besar mendorong terjadinya persaingan yang keras antara produk asing dan produk lokal. Besarnya pasar domestik, akan mendorong pengusaha dan pemasar lokal untuk mengangkat produk merek lokal. Fenomena pemasaran di Indonesia memperlihatkan bahwa produk dari luar negeri masih mendominasi pasar Indonesia (Kuncoro 2016).

Mengangkat merek local merupakan satu langkah yang strategis guna mengenalkan produk buatan Indonesia ke dalam pasar dalam negeri bahkan pasar global. Membangun merek lokal tampaknya tidak mudah untuk dilakukan. Terdapat hambatan internal maupun eksternal yang menghambat pembangunan merek. Dari sisi eksternal, munculnya merek global dengan kekuatan pemasaran global. Di sisi internal, pada umumnya pemasar lebih menyukai merek-merek yang sudah terkenal untuk dipasarkan, ataupun menggunakan merek asing guna memikat konsumen.

Dalam pemasaran, merek mempunyai arti sangat penting. Merek bukan saja identitas suatu produk, namun memberikan image dan daya jual suatu produk (Kotler dan Amstrong 2007). Untuk bisa mengangkat citra produk, diperlukan kebijakan branding yang tepat. Branding adalah penggunaan nama, istilah atau desain atau kombinasi untuk mengidentifikasikan suatu produk (Kotler dan Amstrong 2007). Merek merupakan kombinasi dari feature (what is product), customer benefit, (what need and want the product meet) dan value (what customer assocites with the product). Merek diciptakan untuk menambah nilai terhadap produk dan membedakan dengan produk lain yang memiliki feature yang sama (Kotler dan Amstrong 2008).

Perusahaan Indonesia, seringkali menggunakan kebijakan merek asing guna meningkatkan citra merek produk yang bersangkutan. Diharapkan merek tersebut dapat memberikan persepsi positif yang sejalan dengan karakteristik nama tersebut. peran persepsi dalam pemasaran sangatlah penting. Persepsi suatu produk ,adalah pemilihan, pengorganisasian, dan interpretasi dari stimuli pemasaran dan lingkungan ke dalam suatu gambaran bagi individu (Assael 2001). Persepsi terhadap suatu produk akan mempengaruhi sikap seseorang terhadap produk tersebut.

Bagi pengusaha atau pemasar, penggunaan merek asing dimaksudkan untuk lebih menarik konsumen untuk membeli 
produk tersebut. Karena dengan menggunakan merek asing, image suatu produk diharapkan akan meningkat sehingga produk tersebut akan lebih mempunyai daya tarik, dibandingkan dengan penggunaan merek lokal. Kebijakan menggunakan produk lokal dengan merek asing dinamakan foreign branding. Tujuan utama dari strategi ini adalah untuk mempengaruhi image seorang konsumen. Strategi foreign branding ini digunakan untuk menghindari persepsi yang negatif terhadap suatu produk, atau meningkatkan citra suatu produk. Persepsi yang negatif terhadap suatu produk biasanya dipengaruhi oleh persepsi yang buruk seseorang terhadap suatu produk, yang diasosiasikan dengan negara atau budaya tertentu (peabody dalam Lecrec, Schmitt dan Dube, 1994). Menurut Schiffman dan Kanuk (1995), merek yang menarik akan berdampak terhadap persepsi kualitas (perception of quality).

Berbeda dengan persepsi umum yang terbentuk tentang merek Indonesia, sebagaimana diungkapkan oleh Temporal, (2000) dimana memiliki citra atau persepsi yang poor dan cheap, Khasali (2003) menemukan bahwa ternyata eksistensi merek lokal semakin kuat. Namun demikian Menurut Khasali (2003), pada Negara berkembang termasuk Indonesia merek lokal (local brand) biasanya diidentikan dengan harga murah.

Pada beberapa jenis produk misalnya rokok, kosmetika, kopi, deterjen, dan obatobatan dimana penggunaan produk dengan merek lokal ternyata mampu menandingi merek asing yang dihasilkan perusahaan global. Mereka bukan saja mampu bersaing bukan saja dalam pangsa pasar, namun juga dalam harga.

Banyaknya produk buatan Indonesia dengan merek lokal ternyata mampu menunjukkan kinerja pemasaran yang bagus seperti Kapal Api, Gudang Garam, Teh Sosro, Sari Wangi, Sarimi mampu menunjukkan kinerja pemasaran yang bagus dengan brand image yang positif, sekalipun menggunakan merek lokal, disisi lain terdapat kecenderungan banyak pemasar menggunakan merek asing untuk produk lokalnya untuk meningkatkan citra produknya. Benarkah penggunaan merek asing dapat meningkatkan citra merek apabila dibandingkan dengan penggunaan merek lokal? Benarkah adanya pandangan tentang rendahnya persepsi kualitas dan harga pada produk dengan merek lokal, dibandingkan merek asing? Dalam kategori produk yang mana suatu merek asing memberikan citra merek yang lebih positif dibandingkan dengan produk buatan Indonesia dengan merek lokal? Benarkah merek lokal mempunyai persepsi harga murah?

\section{TINJUAN PUSTAKA DAN PENGEMBANGAN HIPOTESIS}

\section{Merek dan Persepsi Merek}

Dalam pemasaran, peranan merek (brand) sangatlah penting. Secara definisi merek adalah nama, istilah (term), tanda (sign), simbol atau kombinasinya yang menjadi identitas dari suatu produk (Kotler, 2000). Dalam merek terkandung janji dari perusahaan untuk selalu konsiten memberikan features, benefit, dan services kepada pelanggan suatu produk. Merek, selain memberikan identitas kepada suatu produk, juga terkandung image dan asosiasi tertentu yang bisa meningkatkan nilai jual suatu produk atau juga bisa menurunkan nilai jual.

Merek merupakan suatu stimuli yang mendorong konsumen dalam mengambil keputusan pembelian terhadap suatu produk. Stimuli menggambarkan informasi yang akan dipersepsikan oleh konsumen. Nama merek merupakan stimuli ekstrinsik mempengaruhi persepsi konsumen terhadap suatu produk (Assael, 1998). Merek yang sukses, dapat mengikat konsumen sehingga konsumen loyal terhadap suatu produk (brand loyalty).

Adanya stimuli berupa informasi tentang suatu merek akan mempengaruhi perspepsi konsumen terhadap produk atau merek tersebut. Persepsi terhadap produk adalah pemilihan, pengorganisasian, dan interprestasi dari stimuli pemasaran dan lingkungan ke dalam suatu gambaran bagi individu. Persepsi terhadap suatu produk akan mempengaruhi sikap seseorang terhadap produk tersebut. 


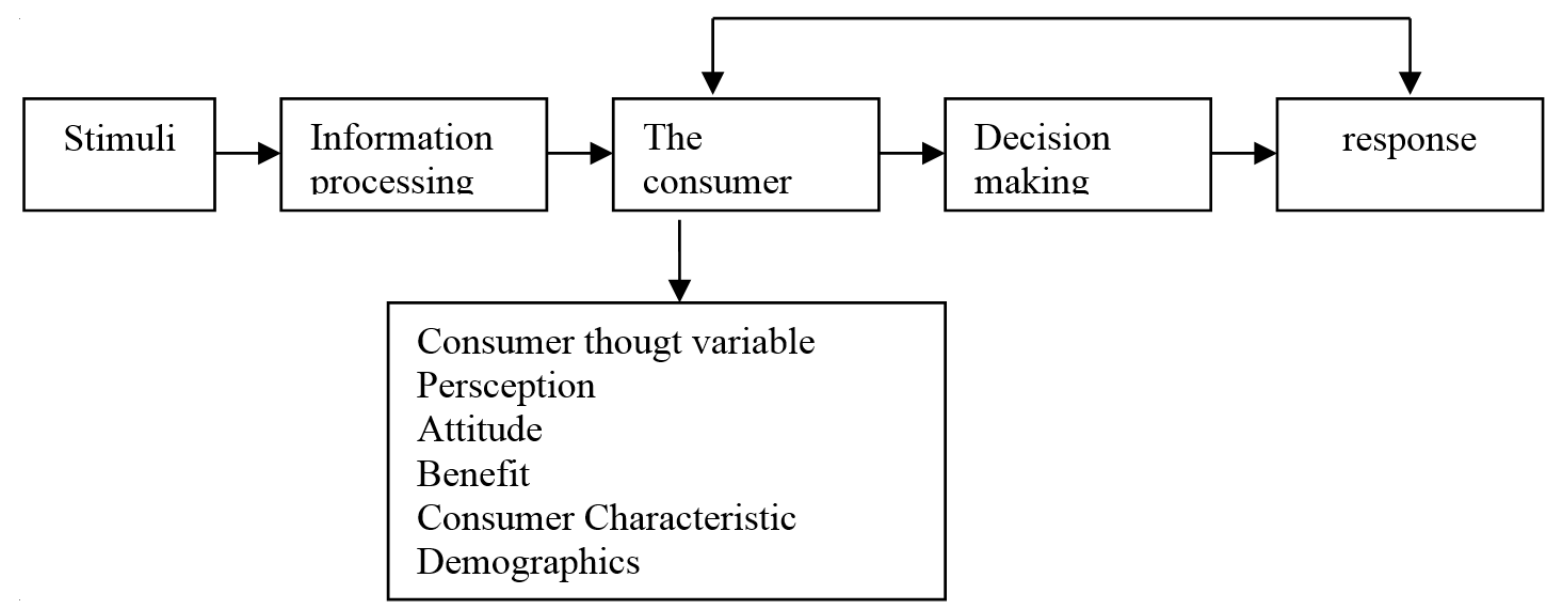

Gambar 1. Model Pengambilan Keputusan Konsumen (Assael, 1998).

Pemasar menggunakan asosiasi merek (brand association), dan brand image guna mencitrakan produknya sedemikian rupa sehingga konsumen mengidentifikasi merek produk tersebut bernilai sama dengan yang pemasar citrakan.Penelitian Lecrec et al (1994), memperlihatkan bahwa konsumen akan mengasosiasikan suatu merek produk dengan suatu kualitas tertentu yang mencerminkan nama tersebut.sebagai contoh es krim merek Haagenz daaz, dipersepsikan oleh konsumen sebagai es krim yang sangat lezat, yang berasal dari Negara Eropa Timur yang terkenal dengan kelezatan es krimnya atau tas merek Giorgio St Angelo sebagai merek tas yang mempunyai kualitas desain yang sangat baik.

\section{Foreign Branding}

Munculnya asosiasi merek dan foreign branding merupakan hasil dari pembangunan merek yang dilakukanoleh suatu Negara selama bertahun-tahun. Jepang dengan merek Toyota, Honda, Sanyo misalnya yang dipersepsikan dengan produk yang berkualitas, dengan harga yang terjangkau merupakan hasil dari sekian lama perusahaan-perusahaan Jepang memasarkan merek tersebut. Sehingga pada akhirnya persepsi atas teknologi yang canggih melekat pada produk-produk buatan Jepang.

Setidaknya ada dua pendapat yang berkembang tentang foreign branding, pendapat pertama, menyatakan foreign branding adalah penamaan suatu produk dengan ejaan asing. Hal ini dikemukakan oleh Lecrec et al. (1994). Pernyataan tersebut mengandung dua kemungkinan. Pertama, merek tersebut betul-betul buatan negara lain dengan ejaan sesuai dengan ejaan negara tersebut, sehingga bagi negara lain, merek tersebut dianggap nama asing. Kemungkinan kedua, adalah penggunaan merek asing namun sesungguhnya produk dalam negeri dengan ejaan asing. Pendapat lain tentang foreign branding adalah semua produk buatan dari luar negeri, sebagaimana yang dikemukakan oleh Batra dan Ciptono.

Terdapat dua dimensi budaya yang mempengaruhi persepsi konsumen terhadap produk yaitu hedonism dan utilitarian. Produk yang dipersepsikan sebagai produk hedonik merupakan produk yang biasanya dinyatakan dalam seberapa besar kesenangan yang dapat diperoleh konsumen apabila mereka mengkonsumsi produk tersebut, sedangkan produk yang dipersepsikan sebagai produk utilitarian akan dinyatakan seberapa baik produk tersebut akan berfungsi.

Penelitian Lecrec et al. (1994), memperlihatkan bahwa suatu mereka berkorelasi dengan Negara asal pembuat produk tersebut (country of origin), dan suatu nama merek dari suatu Negara tertentu akan dipersepsikan dengan features produc hedonic Negara asal tersebut ataupun utilitarian sejalan dengan image yang melekat pada produk dari Negara asal tersebut. Produk yang berasal dari Perancis, misalnya di asosiasikan dengan estetika, rasa enak, elegan dan kecanggihan (sopihiscated). Implikasinya, penggunaan merek yang memperlihatkan merek tersebut dari Perancis, misalnya akan diasosiasikan dengan sentuhan estestika, dan elegan.

Merek global biasanya diidentikan dengan kualitas yang lebih baik. Hal ini ditopang dengan teknologi, modal, sumberdaya 
manusia yang bagus dan manajemen yang modern sehingga mampu menghasilkan produk yang berkualitas. Selain itu, menurut Khasali (2003), merek global masuk ke Negara berkembang dengan global image yang didukung oleh classical marketing methods yang dijalankan oleh kalangan berpendidikan yang dilatih khusus, dengan pengetahuan dan pengetahuan pemasaran dan anggaran yang besar.

Menurut Khasali (2003), pada Negara berkembang termasuk Indonesia merek lokal (local brand) biasanya diidentikan dengan harga murah. Dengan daya beli yang tidak sekuat negara maju, pemasar di negara berkembang mempunyai kecenderungan untuk memainkan variabel harga sebagai komponen utama. Akibatnya merek lokal ditempatkan dimasyarakat Negara tersebut sebagai produk kelas dua.

Dalam studinya mengenai pengaruh asal lokal dan non lokal merek terhadap preferensi merek dan pilihan merek di India, Batra et al. (2000) dalam Tjiptono (2003), mengukur brand locallness/nonlocalness, mereka menemukan bahwa disebagian besar negara berkembang, hampir semua local original brands dijual hanya di pasar domestik dan dinegara lain dapat diklasifikasikan sebagai nonlocal origin brands. Berdasarkan hal tersebut, Batra et al (2000) membagi merek ke dalam merek lokal (Limca, Taaza), nonlocal (Philip, Rolex dst) dan hybrid origin brand (Televisi BPL, Sanyo, Whirpool). Kategori ini mengandung kelemahan mendasar (Tjiptono, 2003). Merek-merek lokal yang diekspor ke banyak negara (contohnya mie instan indomie yang diekspor hampir di 30 negara) bakal dikelompokkan ke dalam nonlocal origin brand. Hal ini tentu saja menyesatkan karena karena bagaimanapun Indomie adalah merek lokal Indonesia.

Tjiptono mengklasifikasikan merek lokal berdasarkan empat kategori, berdasarkan dua dimensi utama: asal (origin) dan kepemilikan (ownership) . Kategorisasi adalah sebagai berikut:

\section{Original local brand}

Kategori ini mencakup merek-merek yang berasal dari negara setempat/lokal dan dimiliki oleh orang/ perusahaan lokal. Contohnya antara lain rokok Jarum Kudus,
Jamu Nyonya Meneer, Kopi Kapal Api, Kompas, KR dll.

\section{Quasi Local Brand}

Kategori ini terdiri dari merek-merek yang berasal dari negara lokal, namun dimiliki oleh perusahaan asing. Kategori ini terdiri atas dua bentuk. Pertama original local brands yang dibeli oleh perusahaan multinasional. Contohnya Ades dibeli oleh Coca-Cola, dan Sari Wangi oleh Unilever.

\section{Acquired Local Brands}

Kategori ini meliputi merek-merek yang berasal dari negara lain, namun dimiliki oleh beberapa orang/ perusahaan lokal.

\section{4. foreign branding}

Kategori ini merupakan kebalikan dari original local brands. Foreign brands berasal dari luarnegeri dan dimiliki oleh perusahaan asing. Contohnya adalah Levi's, McDonal, Pepsi, Adidas, Marlboro, Coca-Cola dan seterusnya.

Sejumlah riset empiris melaporkan bahwa merek-merek global lebih disukai dibandingkan merek-merek lokal, setidaknya dikalangan segmen-segmen konsumen tertentu (Batra et al, 2001, Steenkamp et al, 2003). Secara umum preferensi terhadap merek global dikarenakan kualitas aktual dan perseptual yang lebih unggul, kekaguman atas gaya hidup dinegara maju, preferensi terhadap status simbolik, kosmopolitanisme, dan worlmindedness.

Dari sudut pandang perusahaan, sejumlah faktor diyakini menjadi penyebab mengapa merek global lebih disukai: skala eknomi yang tinggi, telah terbentuknya global village, konvergensi perilaku konsumen, persepsi kualitas lebih unggul, dan jaringan distribusi lebih luas (Kapferer,2002). Walaupun demikian, sebenarnya juga berkembang trend ke arah brand localization yang dipicu oleh desentralisasi pemerintah, individualisasi, pengakuan atas keanekaragaman budaya, dan pemberdayaan konsumen. Konsumen di Australia dan Italia misalnya mulai mengutamakan membeli dan mengkonsumsi produk-produk buatan dalam negeri. Beberapa faktor yang berkontribusi pada preferensi terhadap merek lokal dari sudut pandang perusahaan antara lain: faktor struktural, ekuitas merek, strategi korporat, faktor organisasional, dan faktor lingkungan. 
Penelitian dari Lecrec, Schmitt dan Dube (1994), memperlihatkan bahwa suatu produk Amerika Serikat yang menggunakan merek asing, yaitu nama merek dengan aksen bahasa Perancis dipersepsikan lebih hedonic, dibandingkan merek dengan dengan aksen bahasa Inggris (termasuk merek Amerika). Konsep Frenchness, yang mencitrakan sensivitas estetika, rasa, dan kesenangan, dan kecanggihan, merupakan citra hedonic yang melekat pada Negara Perancis, dapat terwakili pada merek dengan aksen Perancis. Sehingga yang terjadi merek dengan aksen Perancis dipersepsikan lebih hedonic dibandingkan merek Amerika.

Produsen menggunakan foreign branding tentunya tidak hanya mengacu pada ekspolitasi nilai-nilai emosional dari pelanggan, yang dapat terwakili dari merek yang mereka gunakan. Namun juga aspek rasionalitas dari konsumen dimana konsumen juga membutuhkan fungsi utama, selain prestis yaitu kualitas, yaitu seberapa baik suatu produk dapat bekerja sesuai dengan fungsinya (utilitarian). Merek tertentu pada suatu produk, dikenal karena kualitas atau fungsi utama dari suatu produk. Merek-merek Jepang, Jerman, dan Amerika Serikat mampu menggambarkan kualitas tinggi.

Penelitian Lecrerc, Schmitt dan Dube (1994) memperlihatkan bahwa merek beraksen Inggris lebih bercirikan utilitarian dibandingkan merek Perancis, bagi konsumen di Amerika Serikat. Itu artinya merek lokal di Amerika Serikat lebih cenderung dipersepsikan utilitarian oleh konsumen di sana. Merek Asing buatan Indonesia (foreign branding) mengacu pada proses asosiasi kesuksesan merek global, dimana pada umumnya merek global dengan aksen bahasa Inggrsi ataupun bahasa Jepang mewakili suatu kualitas tertentu. Penggunaan merek asing pada produk dalam negeri diharapkan akan memberikan brand image yang positif, pada produk yang mereka buat dibandingkan merek lokal.

\section{Hubungan Harga dan Kualitas}

Sejumlah riset mendukung pandangan dimana konsumen mendasarkan kualitas pada harga. Dengan kata lain, harga adalah indikator dari kualitas (Schiffman \& Kanuk, 1995). Assael menyatakan bahwa ketika konsumen tidak cukup mengetahui tentang kualitas produk, maka mereka akan menggunakan harga sebagai indikator kualitas. Rao dan Moroe dalam Assael (1998) menemukan bahwa hubungan antara kualitas dan harga semakin kuat ketika konsumen kurang cukup informasi atas suatu produk. Selanjutnya Monroe menemukan bahwa ketika responden cukup mempunyai pengalaman dengan merek tersebut, pengalaman merekalah yang menjadi petunjuk dominan atas kualitas, bukan lagi harga.

Beberapa studi memperlihatkan adanya kebijakan perbedaan harga untuk kualitas yang berbeda. Karena harga seringkali seringkali digunakan sebagai indikator dari kualitas, beberapa produk di sampaikan ke pasar dengan harga tinggi sebagai klaim atas kualitas yang mereka punyai. Menurut Schifman dan Kanuk, harga adalah extrinsic cues (petunjuk ekstrinsik), disamping nama merek (brand name) dan imej toko (store image).Brand name, store name, dan price berpengaruh terhadap perceived quality (Dodds, Kent.B dan Dhruv Grewel, 1991).

\section{Hipotesis Penelitian}

1. Terdapat perbedaan persepsi kualitas antara merek asing dan merek lokal pada kategori produk utilitarian.

2. Terdapat perbedaan persepsi kualitas antara merek asing dan merek lokal pada kategori produk hedonik.

3. Terdapat perbedaan persepsi harga antara merek asing dan merek lokal

4. Pada kategori produk utilitarian.

5. Terdapat perbedaan persepsi harga antara merek asing dan merek lokal pada kategori produk hedonik.

\section{METODE PENELITIAN}

\section{Sampel dan Metode Pengambilan Sampel}

Sampel adalah sekelompok obyek yang mewakili populasi yang akan diteliti. Metode pengambilan sampel yang digunakan adalah convienience sampling, yaitu metode pengambilan sampel yang didasarkan pada pemilihan anggota populasi yang mudah diakses untuk memperoleh informasi (Cooper dan Emory, 1995). Peneliti tidak menetapkan kriteria secara spesifik terhadap sampel yang 
digunakan. Dalam hal ini lebih mendasarkan pada kemudahan mendapatkan sampel. Sejumlah 100 sampel diambil dengan convience sampling.

\section{Metode Pengumpulan Data}

Dalam penelitian ini data yang dibutuhkan adalah data primer berupa data tentang persepsi responden masyarakat akan suatu merek produk. Untuk mendapatkan data tersebut, peneliti membagikan kuesioner kepada responden. Peneliti menyebarkan sejumlah 100 kuesioner. Dari 100 kuesioner yang dibagikan, sebanyak 2 kuesioner tidak dapat digunakan, karena tidak memenuhi syarat data.

\section{Obyek Penelitian:}

Dalam penelitian ini obyek penelitian berupa produk dengan kategori produk hedonik dan utilitarian. Produk utilitarian di wakili oleh minuman berenergi, sedangkan produk hedonik diwakili oleh kosmetik. Produk utilitarian adalah produk yang dinilai oleh konsumen berdasarkan fungsi kegunaan, dan manfaat tersebut. Peneliti menggunakan produk minuman berenergi mewakili produk utilitarian didasarkan temuan peneliti sebelumnya (Lestari, 2002), dimana Lestari menemukan bahwa air mineral adalah termasuk kategori produk utilatarian. Peneliti mengganggap terdapat kesamaan sifat antara mimuman berenergi dengan minuman air mineral, sehingga minuman berenergi dianggap layak sebagai proksi dari produk utilitarian.

Adapun merek minuman berenergi yang diteliti adalah Gali Bugar, Kuku Bima JRG, Fit-up, dan Berroca. Gali Bugar dan Hemaviton Jrengg mewakili produk merek lokal. Adapun Fit-Up dan Berroca mewakili merek asing. Adapun produk hedonik diwakili oleh kosmetik. Kosmetik dianggap mempunyai sifat-sifat hedonik (prestise, kesenangan, dan status). Penelitian Lestari memperlihatkan bahwa lipstik dan parfum tergolong produk hedonik. Adapun merek yang diteliti meliputi: Sari Ayu, Cempaka, Mirabella dan Avon.

\section{Instrumen Penelitian}

Data penelitian dikumpulkan dengan menggunakan kuesioner yang disusun dengan tipe pilihan majemuk yang setiap item pertanyaannya berupa pernyataan dengan tujuh pilihan jawaban menggunakan Semantic Differential dengan 7 skala. Untuk variabel persepsi kualitas, rentang pertanyaan mulai dari sangat buruk sampai sangat baik. Untuk variabel persepsi harga, rentang pertanyaan mulai dari sangat murah hingga sangat mahal.

\section{Teknik Analisis Data}

Uji hipotesis dilakukan dengan t-tes untuk sampel berpasangan, Uji Chi-Square Crosstab, dan uji korelasi. Uji t digunakan untuk mengetahui apakah merek asing memberikan brand attitude yang berbeda dengan merek lokal jika diterapkan pada kategori produk tertentu, serta digunakan untuk menguji terdapat tidaknya perbedaan persepsi konsumen atas merek asing dan merek lokal. Sampel berpasangan dipilih karena satu orang responden menjawab dua macam pertanyaan tentang nama merek asing dan merek lokal, untuk satu kategori produk, sehingga dapat diketahui apakah merek asing memberikan brand attitude yang yang berbeda. Uji chi-square digunakan untuk menguji hubungan antara merek asing dan lokal terhadap kualitas dan harga.

\section{Uji Validitas dan Reliabilitas}

Validitas suatu alat ukur memperlihatkan sejauhmana alat ukur dapat mengukur apa yang seharusnya diukur (cooper dan Emory, 1995). Uji validitas dapat digunakan dengan mengacu pada konsep-konsep pengukuran yang telah dilakukan oleh peneliti lain. Instrumen yang digunakan mengacu pada instrumen penelitian dari Lecrect et al. Sebuah instrumen memiliki validitas isi apabila item-item yang digunakan itu sesuai dengan konsep yang diukur. Uji seperti ini memberikan bukti bahwa butir-butir pengukuran yang digunakan untuk memenuhi kriteria validitas isi atau content validity.

Reliabilitas instrumen diukur dengan item to total corelation dan cronbach Alpha yang mencerminkan konsistensi alat ukur. Item to total corellation digunakan untuk menetapkan pengukuran dan mengeliminasi butir-butir yang keberadaanya akan memperkecil koefisien Cronbach Alpha. Suatu alat ukur dinamakan reliabel apabila 
nilai Cronbcah Alpha adalah lebih besar atau sama dengan 0,70. Pada penelitian ini, ketiga variabel $(\mathrm{KH}, \mathrm{HU}$, dan $\mathrm{HH})$ mempunyai nilai Cronbach Alpha di atas 0,7. Hanya variabel kualitas utilitarian yang mempunyai Alpha di atas 0,6. Dengan demikian secara umum alat ukur cukup reliabel.

\section{HASIL DAN PEMBAHASAN}

\section{Deskripsi Responden}

Sebanyak 90 respoden berjenis kelamin perempuan, dan sisanya 8 orang responden berjenis kelamin laki-laki. Apabila dilihat dari tingkat pendidikan, terdapat tiga jenis jenjang pendidikan dari responden yaitu SLTP (2 orang), sma (19 orang ) dan perguruan tinggi sebanyak 77 orang. Dalam hal ini perguruan tinggi tidak dibedakan status D3 atau S1, dan tidak dibedakan antara sedang kuliah atauah sudah lulus.Apabila dilihat dari umur responden, mayoritas responden mempunyai umur 19 tahun (27 orang), dan paling muda berumur 15 tahun (1 orang) dan paling tua berumur 40 tahun (1 orang).

\section{Analisis Data}

Pengolahan data dengan pendekatan chi-square dan uji t- sampel berpasangan, menghasilkan output yang berbeda. Pada kasus pengujian hubungan persepsi kualitas dan harga pada kategori produk utilitarian, dengan menggunakan chi-square tidak terdapat hubungan antara merek lokal dan asing terhadap kualitas dan harga. Adapun ketika memakai uji t sampel berpasangan, terlihat perbedaan yang signifikan antara merek lokal dan asing dalam persepsi kualitas dan persepsi harga.

\section{Persepsi Kualitas Merek lokal dan Asing}

Pada kategori produk utilitarian, merek lokal dipersepsikan mempunyai kualitas yang tidak jauh berbeda dengan merek asing. Sebanyak 37,24\% responden memberikan jawaban kualitas baik, 23,466\% responden menjawab buruk dan sisanya menjawab netral. Sedangkan pada merek asing persepsi kualitas baik dan buruk lebih berimbang, dimana 37,74 responden memberikan pendapat kualitas baik dan 37,2 memberikan pendapat kualitas buruk.
Pada produk hedonik, persepsi kualitas antara merek asing dan merek lokal terlihat berbeda. Apabila responden, memberikan jawaban yang relatif seimbang antara kualitas buruk $(31,19 \%)$ dan baik $(29,52)$ pada merek lokal namun pada merek asing, kualitas baik prosentasenya jauh lebih tinggi 66,66\% dibandingkan $15,4 \%$. Hal ini memperlihatkan bahwa perbedaan kualitas antara merek asing dan lokal terletak pada produk hedonik, sedangkan pada produk utilitarian tidak terdapat perbedaan.

Pada produk utilitarian dengan uji $\mathrm{t}$ sampel berpasangan, persepsi kualitas pada merek asing dikategori produk utilitarian lebih tinggi dibandingkan persepsi kualitas pada merek lokal. Hal ini ditunjukkan oleh skor mean KUF yang lebih tinggi $(4,29)$ dibandingkan KUL $(3,826)$ dan nilai signifikansi,dibawah 0.05 , menunjukkan bahwa kedua sampel mempunyai perbedaan yang nilai rata-rata yang signifikan.

Namun demikian dengan uji hubungan antara merek lokal dan asing pada produk utilitarian dengan kualitas, dengan chi-square test memperlihatkan tidak terdapat hubungan antara merek lokal dan asing terhadap kualitas. Hal ini terlihat dari nilai asymp sig pearson chi-square 0,056 yang lebih besar dari 0,05.

Pada produk hedonik, persepsi kualitas pada merek asing lebih tinggi dibandingkan persepsi kualitas pada merek lokal. Hal ini ditunjukkan oleh skor mean KHF yang lebih tinggi $(4,8)$ dibandingkan $\mathrm{KHL}(2,6)$ dan nilai signifikansi,dibawah 0.05 , menunjukkan bahwa kedua sampel mempunyai perbedaan yang nilai rata-rata yang signifikan. Uji hubungan antara merek lokal dan asing pada produk hedonik dengan kualitas, memperlihatkan terdapat hubungan antara merek lokal dan asing. Hal ini terlihat dari nilai asymp sig chi-square 0,00 yang lebih kecil dari 0.05 .

\section{Persepsi harga merek lokal dan merek asing}

Dalam perspektif harga, perbedaan nyata terletak pada apakah produk tersebut tergolong hedonik ataukah utilitarian. Pada produk utilitarian, responden mempersepsikan harga yang tidak jauh berbeda antara merek lokal dan merek asing. Sebagai contoh pada merek lokal sebanyak 58,67 sebagai produk dengan 
hara murah dan 13,771 dengan harga mahal. Pada merek asing 50,5\% produk utilitarian dipersepsikan sebagai produk dengan harga murah, dan 19,89 persen dipersepsikan sebagai produk dengan harga mahal.

Sekalipunnilaimean darihargapadamerek asing lebih tinggi (HUF,3,36) dibandingkan HUL $(3,29)$ namun nilai signifikansi,di atas 0.05 , yaitu 0,584 menunjukkan bahwa kedua sampel tidak mempunyai perbedaan yang nilai rata-rata yang signifikan.Uji hubungan antara merek lokal dan asing pada produk utilitarian dengan harga, memperlihatkan tidak terdapat hubungan antara merek lokal dan asing dengan harga. Hal ini terlihat dari nilai asymp sig chi-square 0,00 yang lebih kecil dari 0.05 .

Pada produk hedonik, terdapat kecenderungan respoden mempersepsikan harga yang berbeda antara merek asing dan merek lokal. Responden cenderung mempersepsikan merek lokal dengan harga murah, dan merek asing dengan harga mahal. Sebagai contoh pada merek lokal, responden mempersepsikan harga murah sebanyak $39,67 \%$, dan harga mahal sebanyak 19,04\%. Pada merek asing, sebanyak $17,67 \%$ responden mempersepsikan harga murah dan sebanyak $66,33 \%$ harga mahal.

Melalui uji t-sampel berpasangan, nilai mean persepsi harga pada merek asing kategori hedonik (HHF) lebih tinggi
(4,782) dibandingkan HHL (3.510) dan nilai signifikansi,dibawah 0.05 , menunjukkan bahwa kedua sampel mempunyai perbedaan yang nilai rata-rata yang signifikan. Pada uji hubungan dengan Chi-Square memperlihatkan terdapat hubungan antara merek lokal dan asing dengan harga. Hal ini terlihat dari nilai asymp sig chi-square yang lebih kecil dari 0.05 .

\section{Korelasi Harga dan Kualitas}

Pada produk utilitarian, terlihat korelasi yang tidak terlalu kuat antara kualitas dan harga, dimana koefisien korelasi kualitas (KUR) dan harga (HUR), sebesar 0,477.

Pada produk hedonik, korelasi antara kualitas (KHR) dan harga (HHR) menunjukkan korelasi yang cukup kuat dimana koefisien korelasi di atas 0,5 yaitu 0,515 .

Dari sisi persepsi harga, temuan di atas tidaklah mengherankan karena produk kosmetik memang mempunyai harga yang lebih tinggi dibandingkan dengan harga produk minuman berenergi. Berdasarkan teori pemasaran, secara umum terdapat kesesuaian persepsi antara harga dan kualitas. Harga seringkali digunakan sebagai penanda (sinyal) kualitas yang baik dari suatu produk. Konsumen bersedia membeli barang dengan harga mahal karena menginginkan kualitas yang baik.
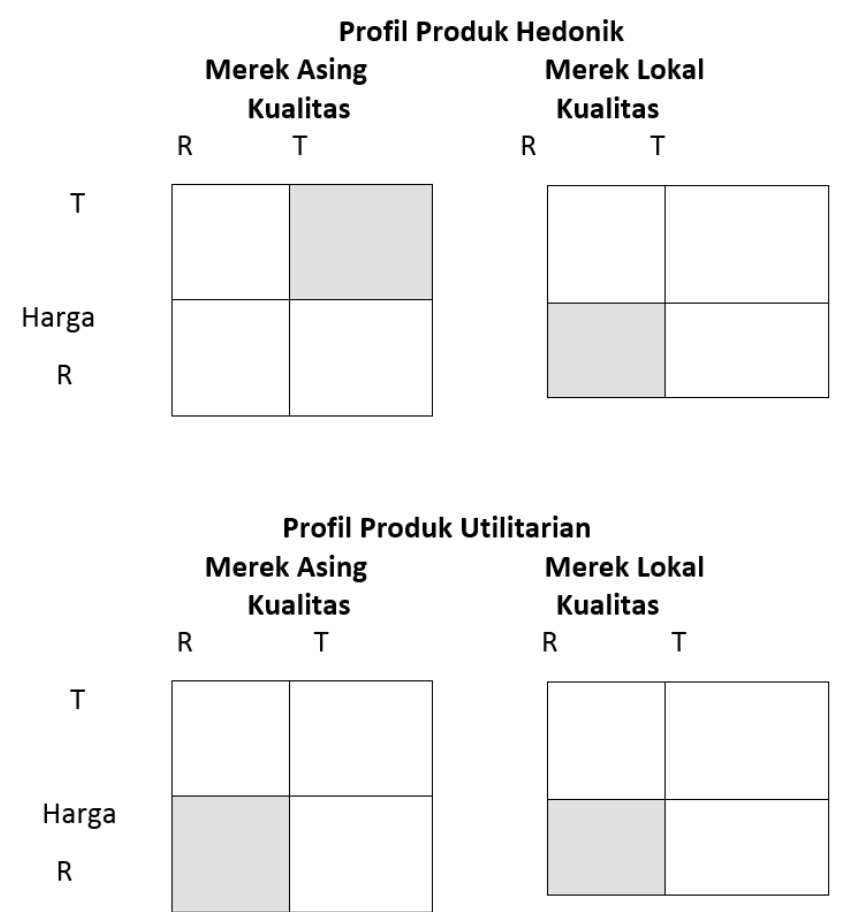

Gambar 2. Profil Produk Utilitarian dan Hedonik 


\section{SIMPULAN}

Berdasarkan hasil temuan di atas maka dapat diambil kesimpulan sebagai berikut:

1. Tidak ada perbedaan persepsi persepsi kualitas antara merek asing dan merek lokal pada kategori produk utilitarian.

2. Terdapat perbedaan persepsi kualitas antara merek asing dan merek lokal pada kategori produk hedonik

3. Tidak ada perbedaan persepsi harga antara merek asing dan merek lokal pada kategori produk utilitarian.

4. Terdapat perbedaan persepsi harga antara merek asing dan merek lokal pada kategori produk hedonik.

\section{DAFTAR PUSTAKA}

Aaker, David A, Kumar, V. And Day, George S (2001), Marketing Research, Seventh Edition, New York, USA: John Wiley and Son. Inc.

Assael, Henry (1998), Consumer Behavior $\&$ Marketing Action, $6^{\text {th }}$, Ed. Cincinati, Ohio,: South-Wetern College Publishing.

Cooper, D.R., and Emory, C.W. Business Research Methods, Irwin, USA, 1995.

Ciptono, Fandy, (2005), Manajemen Pemasaran Global, Andi Offset,
Jogjakarta.

Czinkota, M.R., \& Rainkannen, LA(1996), Global Marketing, International Edition, Orlando, Dryden Press.

Khasali, Rheinald (2003), “ Fenomena Pop Marketing dalam konteks Pemasaran di Indonesia," Usahawan \& Manajemen, No 9, Vol XXXII (September):3:14.

Lestari, Ika , Windy (2002), Penggunaan Asing Pada Produk Hedonik, Utilitarian, dan Hybrid, Skripsi UGM, tidak dipublikasikan.

Lecrec, Peabody and Smith, (1994), “Foreign Branding in Utilitarian and Hedonic Product", Journal of Marketing.

Kotler, Philips (2000), Marketing Management, Millenium Edition, New Jersey, USA; Prentice Hall.

Schifman, Leon \& Kanuk (1995), consumer Behavior, International Edition, Prentice Hall, Singapore.

Sekaran, U., (1992), Research Method for Business, Second edition, New York, John Wiley and Sons.

Temporal, Paul (2000), Branding in Asia, New York, John Wiley and Sons, Inc 